\title{
Traditionally managed landscapes do not prevent amphibian decline and the extinction of paedomorphosis
}

\author{
Mathieu Denoël (D) ${ }^{1,8}$ G. Francesco Ficetola (D) ${ }^{2,3}$ Neftali Sillero (D) ${ }^{4}$ Georg Džukić, ${ }^{5}$ \\ Miloš L. Kalezić, ${ }^{5}$ Tanja Vukov (D) ${ }^{5}$ Irma Muhovic, ${ }^{6}$ Vuk Ikovic, ${ }^{6}$ and Benjamin Lejeune (D) 1,7 \\ ${ }^{1}$ Laboratory of Fish and Amphibian Ethology, Behavioural Biology Group, Freshwater and Oceanic Science Unit of Research \\ (FOCUS), University of Liège, Liège, Belgium \\ ${ }^{2}$ Department of Environmental Science and Policy, Università degli Studi di Milano, Milan, Italy \\ ${ }^{3}$ Université Grenoble-Alpes, CNRS, Laboratoire d'Écologie Alpine (LECA), Grenoble, France \\ ${ }^{4}$ Centro de Investigação em Ciências Geo-Espaciais, University of Porto, Porto, Portugal \\ ${ }^{5}$ Department of Evolutionary Biology, Institute for Biological Research "Siniša Stanković", University of Belgrade, Belgrade, Serbia \\ ${ }^{6}$ Montenegrin Ecologists Society, Podgorica, Montenegro \\ ${ }^{7}$ Laboratory of Oceanology, Freshwater and Oceanic Science Unit of Research (FOCUS), University of Liège, Liège, Belgium
}

Citation: M. Denoël, G. F. Ficetola, N. Sillero, G. Džukić, M. L. Kalezić, T. Vukov, I. Muhovic, V. Ikovic, and B. Lejeune. 2019. Traditionally managed landscapes do not prevent amphibian decline and the extinction of paedomorphosis. Ecological Monographs 89(2):e01347. 10. $1002 / \mathrm{ecm} .1347$

Abstract. Eco-cultural landscapes are assumed to be favorable environments for the persistence of biodiversity, but global change may affect differently their terrestrial and aquatic components. Few long-term studies have examined how multiple, global change stressors may affect wetland biodiversity in such environments. Facultative paedomorphosis is a spectacular example of intra-specific variation, in which biphasic (metamorphosing) amphibians coexist with fully aquatic conspecifics that do not metamorphose (paedomorphs). Paedomorphosis is seriously threatened by global change stressors, but it is unknown to what extent traditional management will allow its long-term persistence. Here, we tested the effects of alien species introductions while taking into account land use and climate changes on the distribution of two polymorphic newt species (Ichthyosaura alpestris and Lissotriton graecus) in Montenegro by using a 68-yr data set and Bayesian mixed models integrating complex spatial and temporal structures. We found that, despite the persistence of natural landscapes, metamorphs dramatically declined and paedomorphs were nearly extirpated, losing $99.9 \%$ of their aquatic area of occupancy and all the major populations. Fish introduction was the main determinant of decline for both phenotypes. Climate and the presence of crayfish further contributed to the decline of metamorphs, which started later and was less dramatic than that of paedomorphs. The near extinction of paedomorphosis on a country-wide scale shows how invasive species determine broad-scale impacts, which can be even stronger than other global change stressors, and underlines the need for immediate management actions to avoid the extinction of a unique developmental process, paedomorphosis.

Key words: alien species; amphibian decline; biodiversity loss; climate change; eco-cultural landscape; fish introductions; freshwater habitats; global change; invasive species; land use; paedomorphosis; traditional landscape.

\section{INTRODUCTION}

Traditional cultural landscapes are the result of centuries of long coevolution between the social and the ecological systems. Within the context of Europe, these systems are thought to have exceptional natural values; several protected species and habitats being maintained by the traditional agricultural and forestry practices (Hartel et al. 2010, Fischer et al. 2012, Rotherham 2015). Aquatic habitats are typical components of

Manuscript received 30 August 2018; revised 20 October 2018; accepted 13 November 2018. Corresponding Editor: Trenton W. J. Garner.

${ }^{8}$ E-mail: mathieu.denoel@uliege.be traditional landscapes. These habitats can serve a wide range of social functions, from recreation to the provisioning of water for humans and livestock (Hammitt et al. 1994, Boix et al. 2012, Hartel and von Wehrden 2013). They are also essential for the persistence of a large diversity of native species because water offers vital resources, such as a place for life, reproduction, development of aquatic larval stages, foraging and hydration (Dudgeon et al. 2006). The Convention of Biological Diversity highlighted the need to protect waters, but there is a lack of data on the long-term evolution of the status of freshwater environments (Williams et al. 2004, Vorosmarty et al. 2010, Abell et al. 2017). However, there is evidence that global changes may have a greater effect on freshwater fauna than on terrestrial fauna 
(Ricciardi and Rasmussen 1999, Bignal and McCracken 2000). It is therefore important to determine the ecological transitions occurring in these habitats, particularly with respect to the globalization of anthropogenic activity, land use, and climatic features (Stoate et al. 2009, Gordon et al. 2010, Plǎiaşu et al. 2012, Hartel et al. 2014). Among freshwater species, amphibians, and more particularly newts, often dominate freshwater habitats such as ponds and mountain lakes (Schabetsberger and Jersabek 1995). Because many amphibian species exhibit a typical biphasic life stage, they are particularly threatened by environmental perturbations acting on both aquatic and terrestrial environments (Semlitsch 2003). One of the important causes of decline in aquatic habitat is the introduction of alien species, such as fish and crayfish (Knapp and Matthews 2000, Orizaola and Braña 2006, Pilliod et al. 2010, Bucciarelli et al. 2014, Havel et al. 2015, Miró et al. 2018). In response to these introductions, populations can collapse or subsist through dispersal to the terrestrial habitat and the use of alternative breeding patches, provided they are available (Winandy et al. 2015, 2017, Tiberti 2018).

Many newt and salamander species express paedomorphosis, a developmental trait that makes them fully aquatic, as it involves the retention of larval traits (e.g., gills) at the adult stage (Fig. 1). This is important in the adaptation and evolution of species (Gould 1977, Denoël et al. 2005b, Bonett and Blair 2017). Whereas it is obligate in some species that lose the ability to metamorphose, it is a polyphenism in other species (facultative paedomorphosis) and, thus, involves the coexistence of both a paedomorphic and a metamorphic phenotype as a response to environmental drivers (Oromi et al. 2016, Mathiron et al. 2017). Yet, a genetic basis of paedomorphosis was found in some species (Voss and Shaffer 1997) and constraining environments can promote metamorphosis over paedomorphosis across generations (Semlitsch and Wilbur 1989). Monitoring the state and temporal change of these particular populations can help inform us about local and global threats to their habitats as well as on both developmental processes. Indeed, the decline of paedomorphs can result from severe, but localized perturbation in the aquatic habitat, while a decline of both phenotypes likely reveals longer-term effects and a larger perturbation as metamorphs can survive, at least temporarily, detrimental waters (Denoël et al. 2009).

Until recently, no long-term studies have examined how multiple, global change stressors affect the diversity of ponds and mountain lakes on a country-wide scale in areas dominated by eco-cultural landscapes. Montenegro is a good candidate in which to investigate the ecological transition of freshwater environments in traditionally managed landscapes because of its geographic location within the Mediterranean hotspots, its richness in many endemic species, its areas with low human population, and the area's prevalence of traditional agricultural and wild landscapes (Griffiths et al. 2004, Mittermeier et al. 2004). Moreover, among Balkan countries, Montenegro
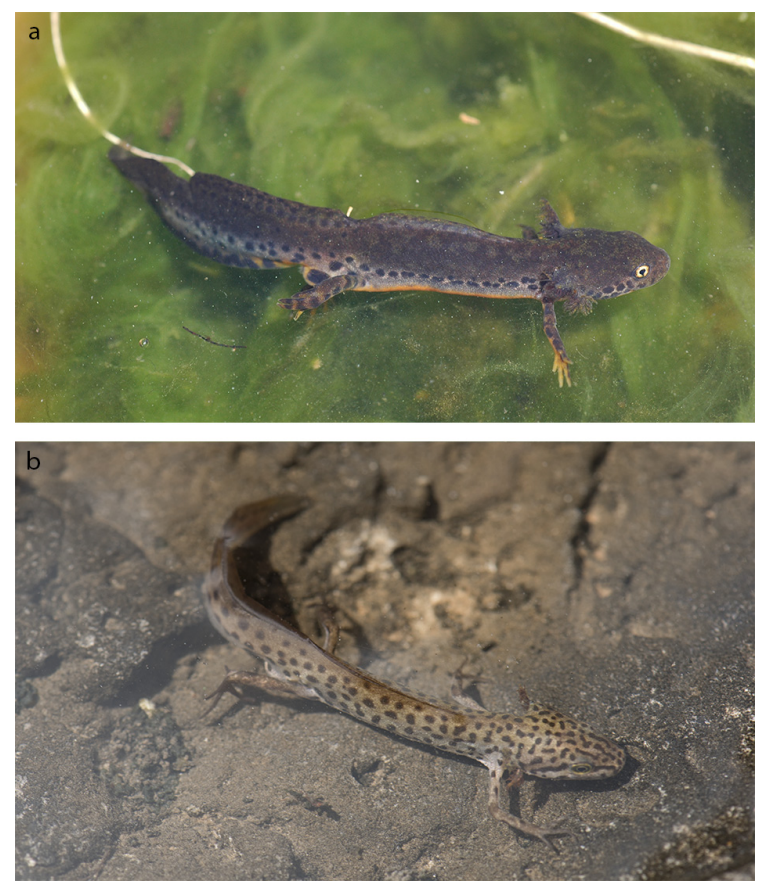

FIG. 1. (a) Paedomorphic alpine newt (Ichthyosaura alpestris) and (b) Greek smooth newt (Lissotriton graecus). This phenotype is characterized by the retention of larval traits, such as gills, at the adult stage. Both pictures depict a male. Photos: Mathieu Denoël.

has historically been known to host numerous paedomorphic populations and endemic taxa (Radovanović 1951, 1961, Džukić et al. 1990) that have been surveyed across decades. Fish introductions were linked to declines in some amphibian populations following a two-step process, involving first the loss of paedomorphosis followed thereafter by metamorphosis. Yet, previous surveys showed the local persistence of the paedomorphs in some sites and the generalized persistence of the metamorphs up to the early 2000s (Breuil 1985, Denoël et al. 2005a, 2009). From this point, it is unknown if both could have recovered, or whether declines continued following the same trend. Because many factors, such as land use and climatic changes, can affect natural populations (Walls 2009, Ficetola et al. 2010), it is important to differentiate their contribution to the ongoing declines from the effects of alien species introductions.

In this study, we took advantage of a data set covering more than $60 \mathrm{yr}$ to assess the impact of multiple threats on the freshwater habitats of the traditionally managed landscapes of Montenegro (Breuil 1985, Džukić et al. 1990, Denoël et al. 2009). We analysed representative sites across Montenegro to assess four phenomena: (1) whether pond and lake environments suffer biodiversity loss, focusing here on amphibians, even if their surrounding terrestrial environment suffers limited habitat loss; (2) the current status and decline of all known populations of paedomorphic newts, including those of endemic taxa as historically described in Montenegro; (3) whether common 
terrestrially adapted phenotypes (i.e., metamorphs) are similarly threatened as are rare aquatic phenotypes (i.e., paedomorphs); and (4) the identification of the potential drivers of decline, focusing on alien species introductions while taking into account land use and climate changes.

\section{Methods}

\section{Studied localities and species}

We focused on the two newt species in which paedomorphosis is the most frequently expressed in the Balkans: the alpine newt (Ichthyosaura alpestris) and the Greek smooth newt (Lissotriton graecus; Amphibia, Salamandridae; Fig. 1). These two species were, until recently, classed within the genus Triturus, whereas L. graecus was formerly considered as a subspecies of Lissotriton vulgaris (Wielstra et al. 2018). In this study, we considered the 23 main localities in which paedomorphosis is expressed in Montenegro (Ćirović 2009, Denoël et al. 2009; M. Denoël, G. Džukić and M. L. Kalezić, personal observations) and for which historical data are available (Appendix S1: Tables S1 and S2). These data came from a combination of our own observations (see also Džukić et al. 1990) and bibliographical data, including data representing type description (Radovanović [1951] for the oldest record). An examination of the conserved specimens (Institute for Biological Research "Siniša Stanković," Belgrade, Serbia) was also done in 2017 to complete our data set and confirm the historical presence of paedomorphosis (Appendix S1: Table S3, Fig. S1; Džukić et al. 2015). Combining bibliographic and direct observations, our data covered 68 yr (1948-2016), with direct surveys covering the period 1970-2016.

\section{Sampling procedure}

Sampling techniques varied across sites due to the differences among the studied freshwater habitats (lakes, ponds, and wells). To limit observer effects across sites, one of the authors (M. Denoël) was involved in all the surveys in the $2010 \mathrm{~s}$, as well as in a number of the historical ones. In all sites, we first used visual sampling techniques by walking around all the water bodies. Then, we used dip-netting of either visually encountered specimens or those that could be taken blindly (i.e., without initial sight) from the most favorable areas (e.g., aquatic vegetation). Moreover, when possible, aquatic rocks were turned over to look for hidden newts. Most surveys were done during one or two visits (several hours minimum per visit), but up to two weeks were spent in the most important historical sites. In the deep Bukumirsko Lake, we also used "minnow" traps in all the benthic microhabitats, including the deepest ones. Traps were built with plastic 1.5-L water bottles from which the neck of the bottle was inverted to point toward the interior of the bottle. Some historical sites (particularly Bukumirsko Jezero and Velika Osječenica) were also highly prospected as part of in depth studies on the evolutionary ecology of newt paedomorphosis (e.g., Kalezić et al. 1996). All sampling followed ethical standards, and the studied newts were released directly back into their habitat of capture after each census.

Failing to observe a species in a site during a particular survey can mean that the species is absent or that it is present but has remained undetected; not taking this issue into account can result in biased inference (MacKenzie et al. 2017). A subset of 11 sites were surveyed multiple times during the same year (average, 2.6 surveys per site; range 2-7), by means of the multiple techniques used in all the surveys. We therefore used occupancy analysis to assess the reliability of the presence/absence pattern (MacKenzie et al. 2017). Occupancy models were run using the unmarked package in R 3.3 (Fiske and Chandler 2011), assuming constant detection probability across all surveys. Occupancy analysis suggested that the per-visit detection probability was very high for both paedomorphic and metamorphic newts. For paedomorphs, the estimated detection probability was $\sim 100 \%$ ( $\mathrm{SE}=0.001 \%$ ), while for metamorphs, the estimated detection probability was $90 \%(\mathrm{SE}=7 \%)$ per visit. Therefore, one single survey was generally enough to ascertain newt occupancy with high reliability and imperfect detection was not a major issue in our data set.

\section{Newt identification}

Newts were identified according to species and phenotype. Paedomorphs were distinguished from metamorphs by the presence of external gills and open gill slits. The adulthood of each individual was established on the basis of a well-developed cloaca (Denoël 2017). Occurrence data on both paedomorphs and paedomorphs of each species at different times allowed us to analyze the timing of their decline. We also recorded the number of individuals caught, but as these data were not available historically for most of the sites, we used only occurrence data. The analysis of ecological correlates of paedomorphosis vs. metamorphosis was performed previously (Denoël et al. 2009); therefore, the present study focused only on the populations that expressed paedomorphosis in at least one survey. All these populations had also historically expressed metamorphosis.

\section{Habitat characterization}

We determined the persistence of the water bodies and recorded the presence of introduced alien species, i.e., fish and crayfish. We calculated the extent of occurrence (EOO) as the minimum convex polygon for each species and the area of occupancy (AOO) as the sum of areas of cells, considering $2 \times 2 \mathrm{~km}$ cells as recommended by the IUCN (IUCN 2017). We also measured the surface area and maximum water depth of each pond and lake and calculated the aquatic area of occupancy (AAOO) as the sum of all occupied surface areas. Finally, we classed water bodies in three categories: lakes, ponds, and wells. 


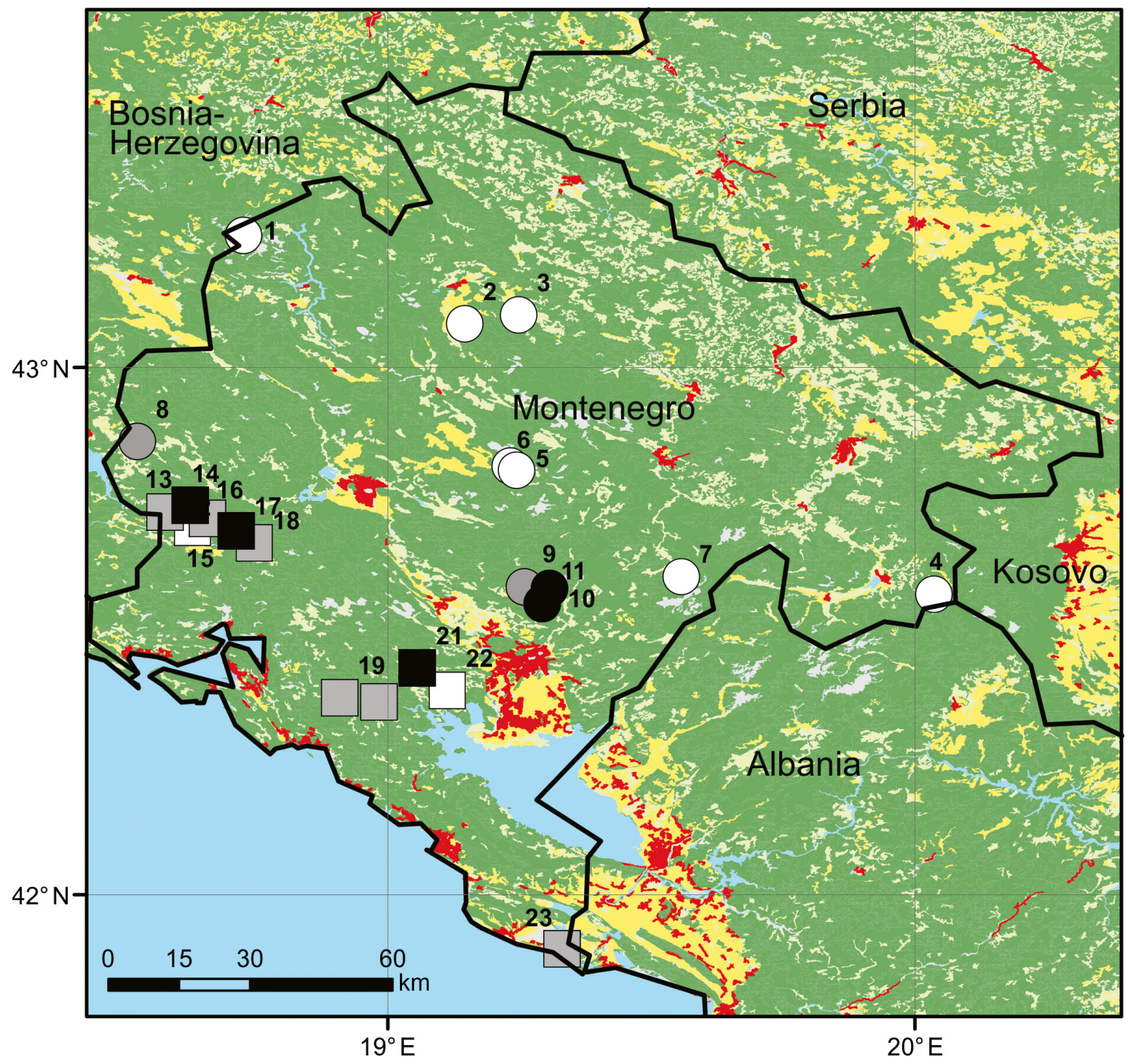

FIG. 2. Amphibian distribution across time: historical (1951-2004), intermediate (2002-2005), and recent (2016) distribution of paedomorphic newts in Montenegro. Circles, alpine newts (Ichthyosaura alpestris); squares, Greek smooth newts (Lissotriton graecus). Black symbols, persistence of paedomorphosis until the last sampling; gray symbols, persistence until the intermediate surveys; and open symbols, disappearance before the intermediate surveys. Background is Corine Land Cover 2012 (dark green, natural vegetation; light green, mosaics of natural and agricultural vegetation; yellow, agriculture; red, urban; blue, water).

\section{Land use}

To determine temporal changes in terrestrial landscapes, we extracted the cover percentage from the Corine Land Cover maps (available online). ${ }^{9}$ We considered natural habitats (Corine Land Cover classes 311-324 and 332) and agricultural lands (211-242). These layers constitute most of the local land use, which can represent favorable vs. potentially unfavorable habitats for newts, respectively. In Montenegro, the natural and traditionally managed lands are typically characterized by low densities of livestock, such as sheep and cows.

\footnotetext{
${ }^{9}$ https://land.copernicus.eu
}

Livestock graze either in semi-open landscapes constituted of bushes and wood patches at mid-elevations or in alpine meadows at the highest altitudes. These lands have very limited use for crops, contrasting with intensive agriculture as commonly found in Western Europe (Lakovic et al. 2016). Impacts on natural lands by farmers have been generally low, as seen by resilience patterns of natural vegetation over the last decades (Nyssen et al. 2014). There were no urban areas, or almost none, around the studied ponds and lakes according to Corine (Fig. 2).

The Corine Land Cover program was started in 1985 by the European Community to generate digital landuse/land-cover maps covering the European continent. 
Analyses were based on four Corine Land Cover maps: the Corine 1990 (generated using satellite images taken during 1986-1988), Corine 2000 (images from 1999 to 2001), Corine 2006 (images from 2005 to 2007), and Corine 2012 (images from 2011 to 2012). All measures of landscape features were computed at two radii (100 and $1,000 \mathrm{~m}$ ) around the periphery of the water bodies. These radii were chosen because they have been shown to act on newt distribution (Denoël and Ficetola 2007, Denoël et al. 2013). The $100 \mathrm{~m}$ radius is expected to have the most importance when directly in contact with water and because most metamorphic newts stay in close proximity to water during their terrestrial phase (Semlitsch 1998, Jehle and Arntzen 2000).

\section{Climate}

As climatic variables, we considered the mean annual temperature and the total annual precipitation during the period before each survey for each locality. Climate was calculated as the mean value considering the year of the survey and the four years preceding years. Climatic data were extracted from the Climatic Research Unit (CRU) 4.01 climate grids (Harris et al. 2014). The CRU 4.01 climate grids contain the monthly values of precipitation and temperature for 1901-2016, on the basis of data collected from meteorological stations over the entire globe. These data have a coarse resolution (resolution $0.5^{\circ}$, i.e., $\sim 50 \mathrm{~km}$ for the study area) compared to the distance among nearby sites, and no high-resolution time series of climatic data were available for the study area. Therefore, we downscaled the CRU on the basis of the CHELSA high-resolution layers of mean annual temperature and calculated the total annual precipitation (30 arc-seconds resolution; Karger et al. 2017), using the change factor approach (Diaz-Nieto and Wilby 2005). The average data of the CHELSA climatology are mean values over the 1979-2013 period. Therefore, we calculated the change factor between the CHELSA data and the average CRU data for the 1979-2013 period, and then used them to downscale the resolution of annual layers. Given that downscaling might produce bias, we also repeated analyses using the CRU data (without downscaling), and obtained nearly identical results.

\section{Statistical analyses}

We used Bayesian mixed models with binomial error distribution to assess the factors determining changes in the distribution of paedomorphic and metamorphic newts in the 23 water bodies, while taking into account multiple typologies of non-independence among observations. As independent variables, we considered six parameters that can determine newt distribution. Two variables represented the distribution of nonnative predators (the presence of introduced fish and crayfish); two variables represented the climate during the years preceding the survey (mean temperature and total annual precipitation); two represented landscape composition during the period of survey (cover of natural vegetation and of agricultural land within $100 \mathrm{~m}$; obtained from the Corine Land Cover data from the closest period). All independent variables were scaled (mean $=0$ and variance $=1$ ) before analyses. The correlation between independent variables was weak $(|r|<0.5$ in all pairwise correlations), suggesting that collinearity was not a major issue for our analyses. Landscape variables were only available since 1985; therefore, we repeated analyses twice: we first analysed the entire data set (1948-2016), not considering land use, and then analysed only data collected after 1984, including landscape as an additional variable.

We used first-order autoregressive models to take into account temporal autocorrelation. We included site identity as a random factor. Furthermore, we used a conditional autoregressive term to take into account spatial non-independence between nearby sites. We repeated these analyses two times. In a first set of analyses, we aimed to assess the overall causes of the decline of paedomorphs and metamorphs, without focusing on interspecific differences; therefore, we included species identity as a random factor. In a second set of analyses, we tested whether there were interspecific differences in the response to threats. Therefore, we included species identity as a fixed factor, and we also tested the interactions between species identity and the threatening factors. We used the Integrated Nested Laplace Approximations (INLA) approach to fit mixed models and calculate 95\% credible intervals (CIs). INLA is a computationally effective and extremely powerful alternative to Markov chain Monte Carlo to run Bayesian models, which is particularly appropriate for data sets with complex spatial and temporal dependencies (Bivand et al. 2015, 2017, Rue et al. 2017).

\section{Results}

\section{Historical distribution of paedomorphosis}

Both phenotypes (i.e., paedomorphs and metamorphs) have been described in 23 localities of Montenegro (11 for the alpine newt and 12 for the Greek smooth newt; Fig. 2, Appendix S1: Tables S1 and S2). Examination of the museum collections of 19 historical localities and field verifications in the four remaining localities confirmed the sexual maturity of gilled newts, i.e., their paedomorphosis in all of the 23 studied populations (Appendix S1: Table S3, Fig. S1). This sample represents almost all the populations of paedomorphs in Montenegro (all major ones), as very few additional mentions of occurrence were available (i.e., three records in museum, only one in the literature; Denoël et al. 2005a) but not usable here given the lack of data.

The aquatic habitats where paedomorphs were historically found encompassed mountain lakes $(30 \%)$, ponds $(52 \%)$, and wells (17\%; Appendix S1: Fig. S2). Sixty-four percent of populations of paedomorphic alpine newts occurred in lakes, whereas all paedomorphic Greek smooth newts were found in ponds and wells. The lakes, 
ponds, and wells had surface areas of $79 \pm 24 \mathrm{~m}^{2}$, $432 \pm 129 \mathrm{~m}^{2}$, and $18 \pm 3 \mathrm{~m}^{2}$, respectively (mean $\pm \mathrm{SE}$ ). All aquatic habitats were permanent and deep (water depth of lakes $=14.0 \pm 4.3 \mathrm{~m}$, ponds $=2.2 \pm 0.3 \mathrm{~m}$, and wells $=2.6 \pm 0.8 \mathrm{~m}$ ). See Appendix S1: Table S1 for details on the aquatic habitats.

\section{Land use and climate changes}

The cover of forests and shrubland was, on average, $>60 \%$ if measured within a $100-\mathrm{m}$ buffer, and $>70 \%$ if measured within a 1,000-m buffer (Appendix S1: Table S4, Fig. S3). The agricultural cover was generally limited (Appendix S1: Table S4). In 2012, landscape changes were generally limited. Agricultural cover remained stable and natural vegetation showed an increase of approximately $18 \%$, which corresponded to a decrease in mosaics between agricultural and natural lands (Fig. 2; Appendix S1: Fig. S3, Table S4). Only one of the studied aquatic habitats was destroyed during the study period.

Climatic parameters showed strong variation throughout the study period. Total annual precipitation showed strong variation among these years, but we did not detect obvious long-term trends (Appendix S1: Fig. S4). For temperature, in the study sites, there was a trend toward warmer mean annual temperature, particularly after 1980. The average annual temperature of the last years was roughly $1.5^{\circ} \mathrm{C}$ higher than average temperatures of the 1970s (Appendix S1: Fig. S4).

\section{Freshwater habitat deterioration}

Major disturbance was found in $57 \%$ of the studied Montenegrin freshwater habitats $(100 \%$ of lakes, $25 \%$ of ponds, and $25 \%$ of wells). Considering the specific habitats of alpine and Greek smooth newts, $73 \%$ and $42 \%$ of the water bodies were disturbed, respectively. The most frequent observed disturbance was the presence of aquatic alien species, notably fish (52\%) and crayfish (17\%), and these disturbances occurred over the whole of Montenegro (Fig. 3; Appendix S1: Table S5). In habitats with fish, there were, on average, 2.5 fish species present (range 1-6 species), belonging to Salmonidae, Cyprinidae, and Ictaluridae; all crayfish were Astacidae. All lakes had introduced fish, and all localities with invasive crayfish also had introduced fish. Introductions took place in all types of habitats, except wells. Only one case of crayfish introduction was observed in the 2000s, the others occurring after 2010.

\section{Paedomorphic newt decline}

Paedomorphs of both the alpine and Greek smooth newts have declined progressively since their historical discovery (Fig. 4; Appendix S1: Table S6). During the 2000 s and 2010s surveys, paedomorphs were found in $57 \%$ and $22 \%$ of the historical localities, respectively (Figs. 2 and 4; Appendix S1: Table S2). For paedomorphic alpine newts, in the 2000 s, only $36 \%$ of historical populations persisted, and only $18 \%$ of populations persisted in the 2010s. For paedomorphic Greek smooth

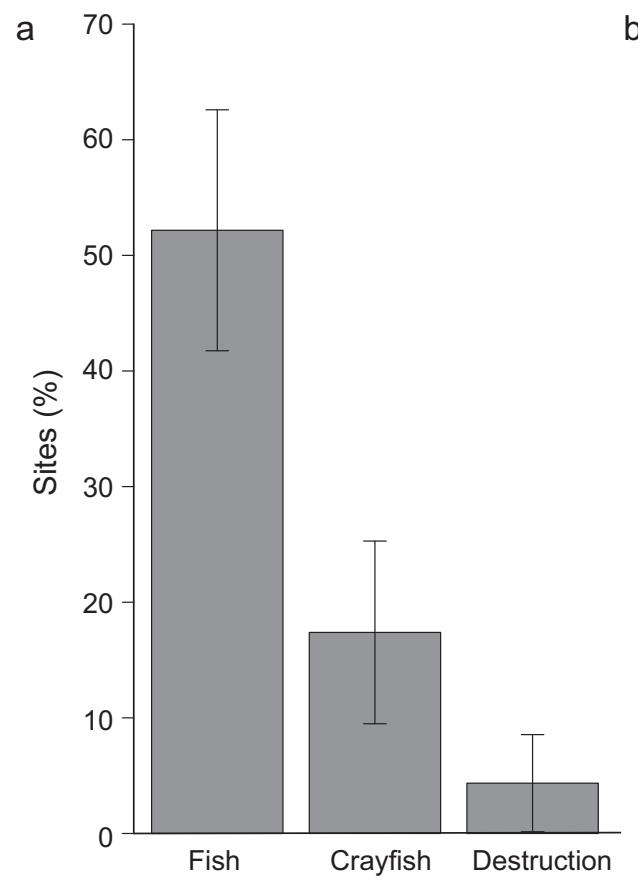

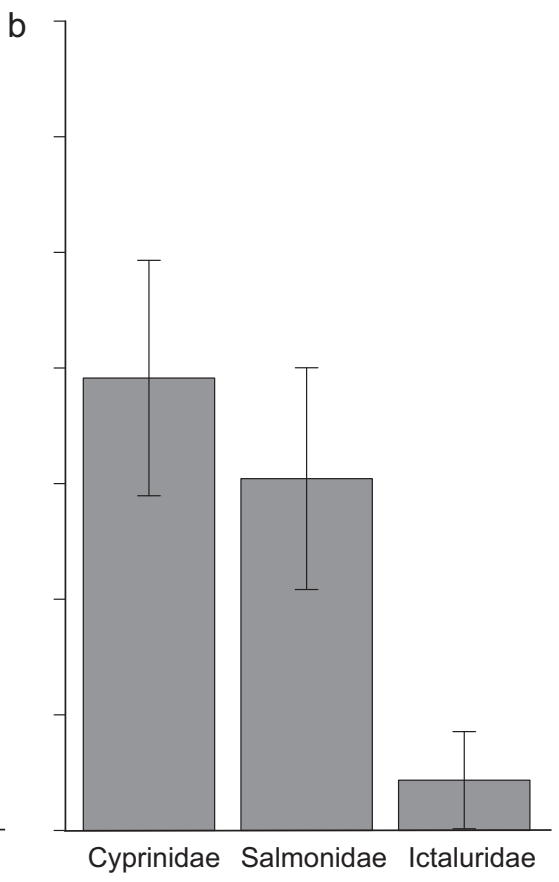

FIG. 3. Main local threats to freshwater habitats (lakes and ponds) of Montenegro: (a) proportion of sites with introduced fish and astacid crayfish and those destroyed; (b) proportion of sites fished with cyprinids, salmonids, and ictalurids. Values are means and SE. 

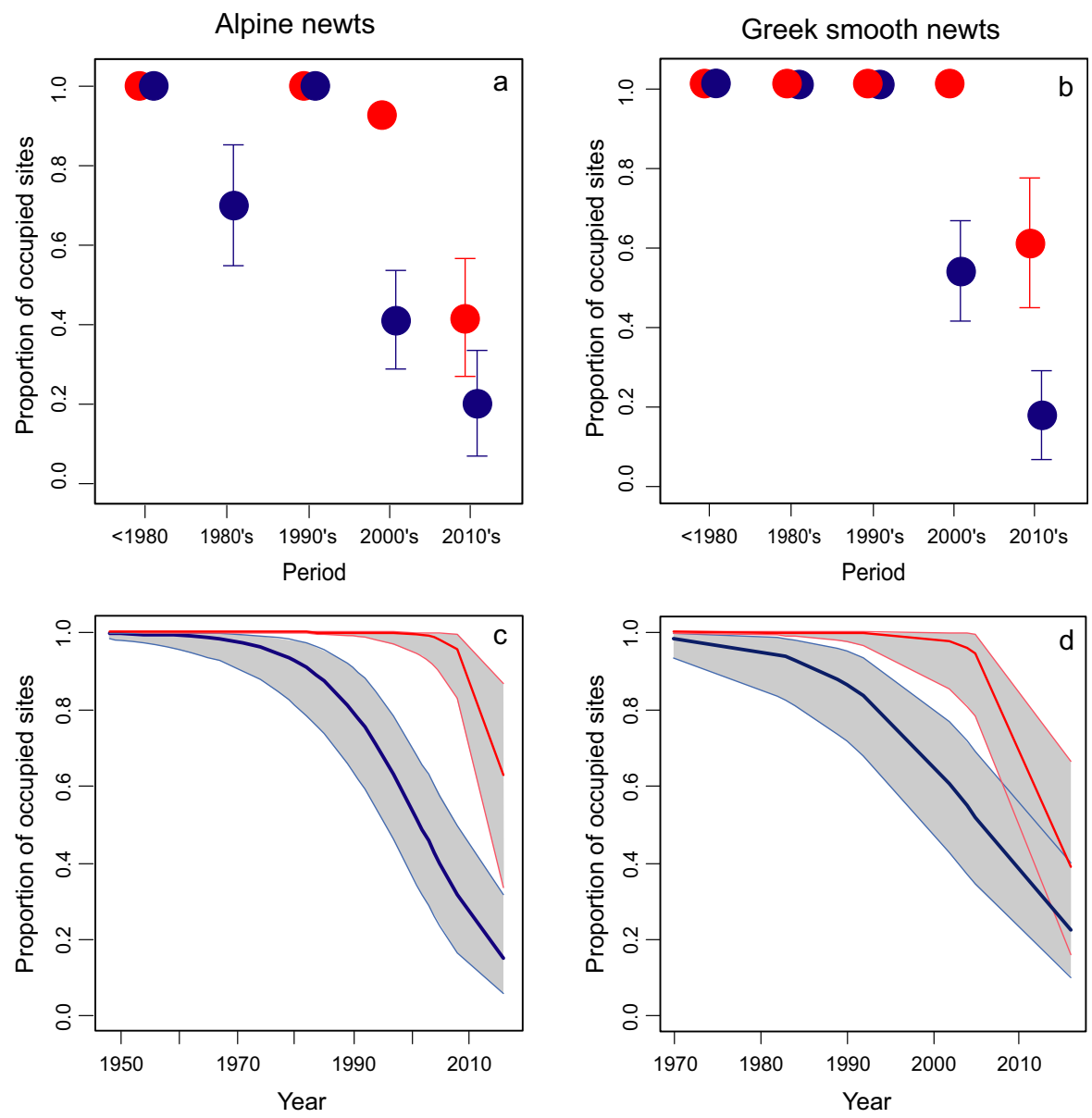

FIG. 4. Decline of paedomorphic and metamorphic alpine newts and Greek smooth newts in traditional landscapes of Montenegro. (a,b) Observed frequency (mean $\pm \mathrm{SE}$ ); (c,d) frequency fitted using generalized mixed models. Blue, paedomorphs; red, metamorphs. Shaded areas represent $95 \%$ confidence intervals.

newts, in the 2000 s, $75 \%$ of historical populations persisted, and only $25 \%$ of populations persisted in the 2010s. No paedomorphs subsisted in lakes, while they persisted in $17 \%$ of ponds and in $75 \%$ of wells.

The extent of occurrence (EOO), the area of occupancy (AOO based on $2 \times 2 \mathrm{~km}$ grid cells), and the aquatic area of occupancy (AAOO based on the surface of water bodies) dropped considerably in both studied species since their historic record began. Alpine newts lost $99.99 \%$ of EOO, $81.81 \%$ of AOO, and $99.99 \%$ of AAOO, while Greek smooth newts lost $97.2 \%$ of EOO, $83.33 \%$ of AOO, and $95.41 \%$ of AAOO (Fig. 5). During the last decade (2000s to 2010s), the decline in EOO, AOO, and AAOO was $99.99 \%, 73.68 \%$, and $50 \%$ in the alpine newt, and $95.40 \%, 92.82 \%$, and $77.78 \%$, respectively, for the Greek smooth newt (Fig. 5).

Bayesian autoregressive mixed models showed that fish presence was the main driver of paedomorph extirpation. When we analysed the entire period, there was a strong negative relationship between fish and paedomorph presence in ponds, while the CIs of climatic and land cover variables, as well as crayfish presence, widely overlapped zero (Fig. 6).
Results were similar when we focused on the period 19852016, and we did not detect any relationship between paedomorph persistence and landscape variables (Fig. 6).

When we considered species as a fixed factor, we observed a slightly lower persistence rate for Greek smooth newts, but the CIs overlapped zero (Appendix S1: Table S7). Models were similar to the ones considering species identity as a random factor (Appendix S1: Table S7). When we added the interactions between species and independent variables to this model, none of them was significant, suggesting a similar response to the different stressors across species.

\section{Metamorphic newt decline}

Although metamorphs remained present in all sites in the early 2000 s, they were only found in $52 \%$ of localities in the 2010s (lakes $43 \%$, ponds $50 \%$, wells $75 \%$ ). They declined significantly later than paedomorphs in both species (non-overlap of CI bands; see Fig. 4).

Some metamorphic newts could still be found in sites with fish, but they were fully or almost fully absent in 

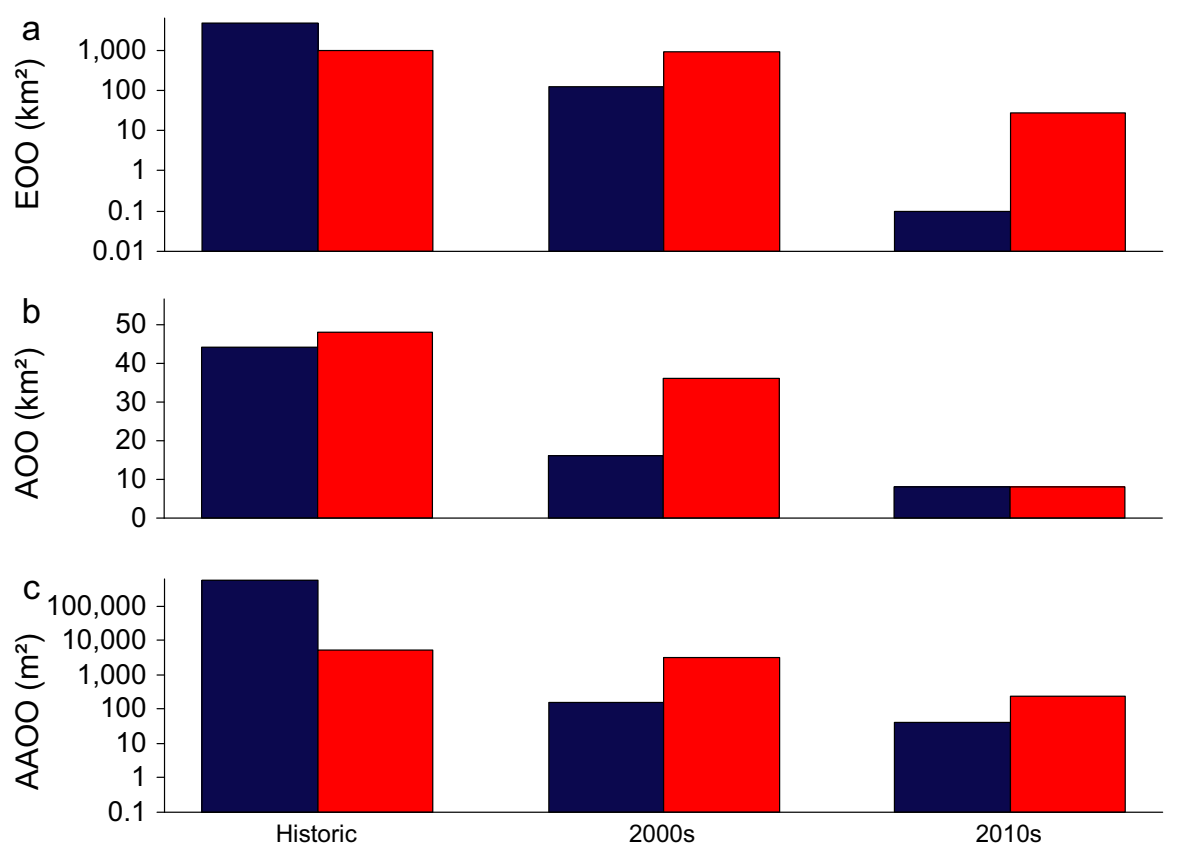

FIG. 5. Global change in the amount of habitat use in Montenegro by paedomorphic alpine newts (blue bars) and Greek smooth newts (red bars): (a) extent of occurrence (EOO), (b) area of occupancy (AOO; based on $2 \times 2 \mathrm{~km}$ grid cells), and (c) aquatic area of occupancy (AAOO; based on surface area of water bodies) at the historical maximum (all known populations) in the 2000 s and in the 2010s.

places where crayfish had been introduced. Autoregressive mixed models showed that invasive species and climate can act jointly, determining the extirpation of metamorphic newts. When we analysed the whole period, there was a strong negative relationship between fish and metamorph presence in ponds. The effect size of climate and crayfish presence was weaker than the effect size of fish presence. Nevertheless, the $95 \%$ CIs of these variables did not overlap zero, suggesting a negative relationship between metamorph persistence and crayfish presence, and between metamorph presence and mean annual temperature during the years before the survey (Fig. 6). Results were identical when we focused on the period 1985-2016. Fish presence showed the strongest negative effect size; crayfish presence and temperature during the previous years showed negative effect sizes with $95 \%$ CIs not overlapping zero; while we did not detect any relationship between metamorph persistence and precipitation or landscape variables (Fig. 6).

When we considered species as a fixed factor, we observed a lower persistence rate for Greek smooth newts (Appendix S1: Table S7). The credible intervals of the two interactions (species $\times$ crayfish presence and species $\times$ cover of natural habitat) did not overlap zero. Crayfish presence more strongly affected alpine than Greek smooth newts, as $75 \%$ of crayfish occurrences affected alpine newts. An interaction between natural habitat and species identity suggested that alpine newts suffered from the change of surrounding habitat more than Greek newts.

\section{Discussion}

Whereas terrestrial environments showed limited alterations in the studied eco-cultural landscapes, the associated aquatic landscapes have been deeply affected over the last decades. The main driver of change was the introduction of alien aquatic species, which persisted and expanded over the last decades. This resulted in a rapid biodiversity loss as shown by the high decline of amphibian populations. Even worse, the fully aquatic and rare paedomorphic phenotypes are now on the edge of extinction on a country-wide scale. Although Montenegro was historically a hotspot of the unique evolutionary process that is paedomorphosis (Džukić et al. 1990), this is no longer the case. Because newts and, even more specifically, paedomorphs used to be the native top predators of these freshwater habitats, the current situation is, therefore, more than just alarming, suggesting that many of these aquatic ecosystems may be globally impacted.

In Western Europe, terrestrial lands are deeply affected by anthropogenic change, and the alteration and disappearance of freshwater habitats have been well documented on a variety of scales (Wood et al. 2003, Ferreira and Beja 2013, Arntzen et al. 2017). In many cases, the remaining aquatic habitats became less favorable for the establishment of native aquatic fauna (Ficetola et al. 2011, Denoël et al. 2013). In contrast, it is often assumed that alpine environments 
Period: 1948-2016
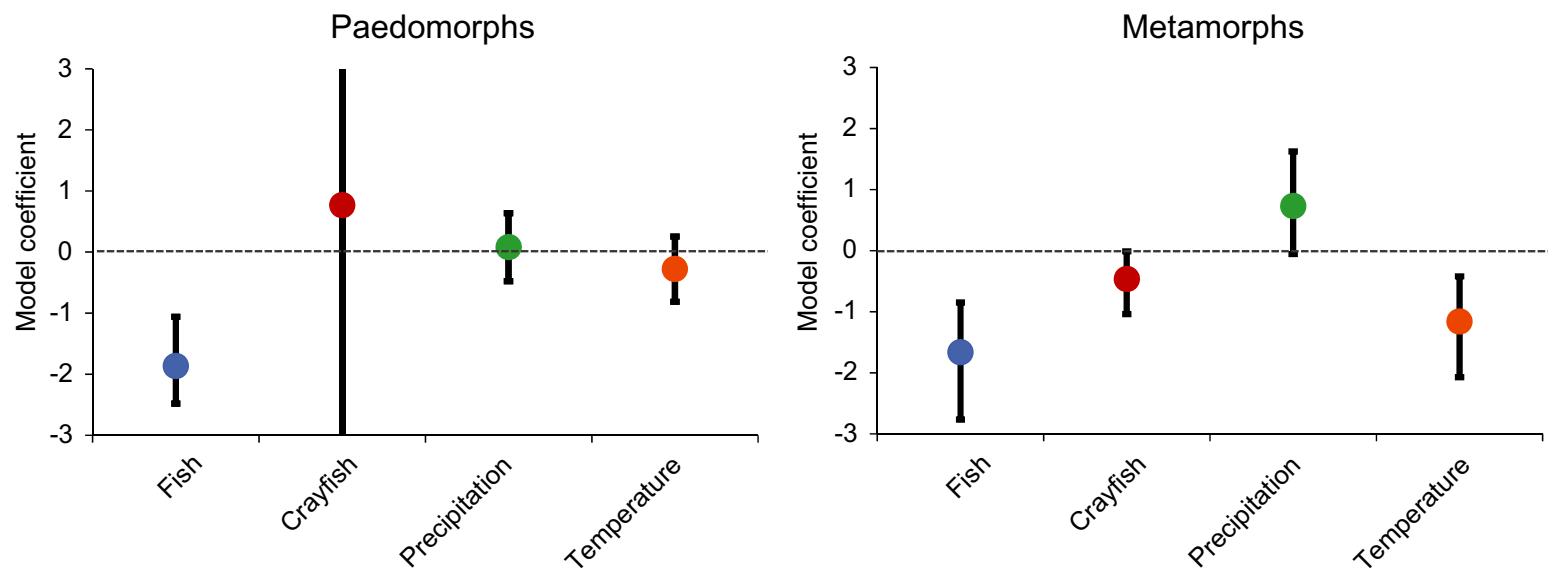

Period: $1985-2016$
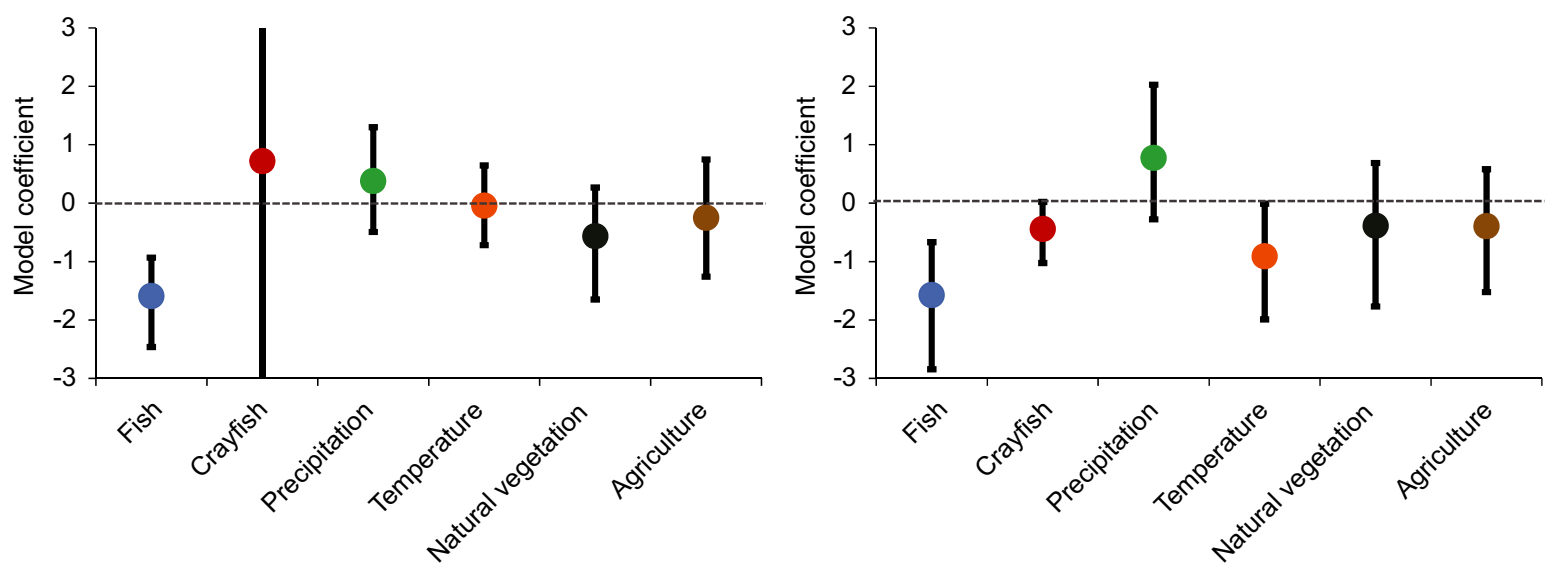

FIG. 6. Bayesian mixed models of the effect of environmental and climatic variables on the decline of paedomorphic and metamorphic newts. Whiskers denote $95 \%$ credible intervals.

and other traditionally managed lands continue to offer valuable resources to sustain biodiversity (Hartel et al. 2010, Rotherham 2015). Although agricultural practices are rapidly changing in Eastern European countries (Pătru-Stupariu et al. 2016, but see Miró et al. 2018), there was no generalized increase in agricultural lands in the proximity of ponds and lakes in the present study. In most cases, the landscape remained natural with even a decrease in some agricultural typologies (i.e., agriculture mosaics), a sign of land abandonment and reduced use of natural resources (see also Nyssen et al. 2014, Lakovic et al. 2016). However, ponds, which were historically used primarily for water sources for humans and livestock, are now often redirected to new objectives, such as fish stocking. This exemplifies a major and worrying change in thinking on the value and use of water resources in rural environments, which can have significant negative impacts on biodiversity.

\section{Declines over the last decades}

Previous reports highlighted the decline of amphibians, including newts on a global scale, (Denoël 2012, Dufresnes and Perrin 2015, Drechsler et al. 2016, Arntzen et al. 2017), and paedomorphic newts have suffered particularly dramatic population losses (Denoël et al. 2005a). In Montenegro, the first report of paedomorph extirpation dates back to the 1980s (Breuil 1985), whereas the first global survey in the early 2000s showed a strong decline that altered the distribution of paedomorphs, but caused no changes for metamorphs (Denoël et al. 2009). Our results show that paedomorphs are now only present in one-fifth of the historical sites. Only a few paedomorphs were observed in the remaining populations, suggesting that the large historical populations no longer exist. With a maximum of 13 paedomorphs found at a single site (all populations considered) in 2016, the situation contrasts radically with what existed 
more than $30 \mathrm{yr}$ ago, when populations of up to 1,000 paedomorphs could be found in ponds and in lakes (Džukić 1981, Kalezić and Džukić 1985, Kalezić and Dzukiž 1986, Kalezić et al. 1989). The proportion of paedomorphs within populations also dropped significantly. Indeed, some populations were predominantly paedomorphic in historical surveys (e.g., 86\% paedomorphs in Bukumirsko jezero; Kalezić et al. 1989), whereas paedomorphs were either extinct or found in very low proportions during the latest survey (i.e., maximum 7\% in Rutešića voda), therefore showing an extinction of all populations that were mainly paedomorphic. We also point out that the observed declines are not due to turnover in metapopulations (Cruickshank et al. 2016) because there was no potential population source of paedomorphs near the study populations.

The present survey showed a much more serious decline than in other diversity hotspots where both phenotypes declined but persisted (Crochet et al. 2004, Denoël et al. 2005a, Denoël and Winandy 2015). Countries near Montenegro were also known to host populations of paedomorphic newts (Džukić et al. 1990, Denoël et al. 2001, Papaioannou et al. 2015, Sotiropoulos et al. 2017). However, the most important populations of alpine newts also disappeared in Bosnia and Herzegovina and Slovenia (Denoël et al. 2005a). Some extinct paedomorphic populations were unique and were historically described as endemic subspecies (Radovanović 1951, 1961). This is the case of Ichthyosaura alpestris montenegrina in Bukumirsko Jezero, I. a. serdara in Zminičko Jezero and $I$. a. piperiana in Kapetanovo and Manito Jezero. In all cases, paedomorphs disappeared from the type localities, whereas metamorphs also vanished or largely declined (see also Džukić 1995, Denoël et al. 2005a). Such continuous decline overcomes thresholds defined by the International Union for the Conservation of Nature (IUCN) to identify critically endangered taxa (IUCN 2017). Localized extinctions have also been reported for lakes inhabited by paedomorphs in other families, such as ambystomatids, including the axolotl (Ambystoma mexicanum), which is now nearly extinct (Whiteman and Howard 1998, Contreras et al. 2009), further stressing the high conservation concern of paedomorphosis.

\section{Anthropogenic pressures on freshwater habitats and amphibians}

Multiple factors drive biodiversity loss on the global scale. Invasive species, land use conversion and climate change are among the most threatening factors (Sala et al. 2000, Bosch et al. 2018). The introduction of nonnative species, particularly fish, was the main driver of the decline of both metamorphic and paedomorphic newts (Fig. 4). Fish stocking started in alpine lakes of Montenegro in the 1970s, and continued in the last decades, particularly in ponds. The presence of young-ofthe-year indicated reproduction at several sites. The lakes that were already fished in the early 2000s continued to be stocked with fish, and multiple species were often introduced in the same lake. Introductions involved fish as varied as cyprinids, catfish, and salmonids, with up to six species found in a single lake. The presence of such alien fish communities is very detrimental to native species because they are expected to occupy varied niches of the freshwater habitats and profoundly impact native food webs (Havel et al. 2015, Gallardo et al. 2016, Cabrera-Guzmán et al. 2017). For instance, the larger and more predatory species can impact newts by predation, as shown by the stomach contents of 11 salmonids, which contained 15 paedomorphic alpine newts at the time of introduction in Bukumirsko Jezero (Denoël et al. 2005a; A. Ivanovic, personal communication). In addition to consumptive interactions, fish can also be competitors and be aggressive toward newts and salamanders (Zambrano et al. 2010, Winandy and Denoël 2015).

An interesting pattern evidenced by the present study is that metamorphs manage to persist in ponds and lakes longer than paedomorphs in the presence of fish (Fig. 4). This differential response of both phenotypes could be explained by different factors. First, the fully aquatic life of paedomorphs exposes them to fish all year round and prevents them from leaving water bodies with fish by dispersal on land, whereas metamorphs are able to do so (Winandy et al. 2015). Second, it has been suggested that metamorphs in water bodies with fish could come from nearby fishless ones, i.e., through a source-sink dynamic process (Breuil 1985). Third, paedomorphic newts are more pelagic than metamorphs and, therefore, are more easily preyed upon by large predators such as salmonids (Denoël et al. 2005b, Lejeune et al. 2018). Unfortunately, the longer persistence of metamorphs proved to be, in most cases, only a transient state, given that in the last years they showed a pattern of decline comparable to the one of paedomorphs in the 2000s.

In addition to fish, the last survey detected crayfish, which are a new threat to newts. Although not seen historically and found in only one of the studied ponds a dozen years ago (Ćirović 2009; M. Denoël, personal observation), crayfish have now been introduced in four localities, including both ponds and lakes. Crayfish are among the most important invasive components of freshwater ecosystems worldwide, with the potential to have significant detrimental effects on whole communities due to their omnivorous feeding behavior and intense burrowing activity (Rodríguez et al. 2005, Gherardi 2010). Their recent invasion in numerous countries raises important concerns for amphibians and, even more, newt conservation (Gamradt and Kats 1996, Cruz et al. 2006, Ficetola et al. 2011, 2012). The effect of crayfish in Montenegro was particularly detrimental as shown by the disappearance of both newt phenotypes following crayfish introduction.

Finally, mixed models showed that climate change affected the metamorphic phenotype in the studied populations. Although drought events can affect 
populations of paedomorphs in other areas (Semlitsch and Gibbons 1985, Denoël and Winandy 2015, Mathiron et al. 2017), it is less likely the case in Montenegro because most ponds and lakes are very deep, making them permanent aquatic habitats. In contrast, high temperatures were associated with a decrease in the occurrence of the metamorphs, the terrestrially adapted phenotypes. Despite the fact that microhabitats could buffer the impact of climate change (Scheffers et al. 2014), this result constitute recent evidence that global warming could affect amphibian populations (Walls 2009, Bonett et al. 2014, Ficetola and Maiorano 2016).

\section{Is there still hope for amphibians and paedomorphosis?}

Despite perturbations and declines, many species are able to show resilience after threat removal (Knapp et al. 2001). This is the case in amphibians (Vredenburg 2004, Knapp et al. 2007, 2016, Milligan et al. 2017), and even paedomorphic newts, after fish removal (Denoël and Winandy 2015). Indeed, as facultative paedomorphosis is a polyphenism, some metamorphic dispersers from populations where facultative paedomorphosis is expressed can give birth to individuals that can mature as paedomorphs (Denoël and Winandy 2015, Oromi et al. 2016). However, selection against paedomorphosis can alter its expression (Semlitsch and Wilbur 1989), which might decrease the likelihood of the resilience of paedomorphic populations after a long period of time of counter selection, as is probably the case in Montenegro. Moreover, as there are no remaining populations of paedomorphs near the studied populations, colonizers would come only from populations of metamorphs (see also Oromi et al. 2019). In fact, fish were extirpated in one of the mountain lakes (Ridsko Jezero), but paedomorphs did not recover as only metamorphic newts were found during the last surveys.

Fish removal could be performed in both ponds and lakes, but this often requires long-term actions (Knapp and Matthews 1998, Tiberti et al. 2017). These management aspects were therefore not in the scope of the present study whose primary aim was to show the ongoing decline and to raise awareness that the extinction of paedomorphs, and consequently of the process itself, is likely to occur globally if no conservation measures are taken. In developing countries, such as Montenegro, management may be particularly challenging. On the one hand, the recent fishing interest of local people and the abandonment of the traditional use of ponds (i.e., providing water sources for humans and livestock) make it likely that new introductions will occur after management. On the other hand, no significant management activities or funding have been devoted as yet to freshwater biodiversity conservation in Montenegro. Thus, local enforced protection along with raising awareness should be promoted in parallel with all removal actions. For instance, fishing bans helped in preventing new fish introductions in Pyrenean alpine lakes (Miró and Ventura 2013).
It is possible that some new populations of paedomorphs could still be discovered. However, all major alpine lakes have already been intensively surveyed in Montenegro (Denoël et al. 2009); therefore, it is likely that no new major populations would be found. In principle, it is also possible that paedomorphosis could still be expressed later in some of the studied ponds, despite the absence of observation during the last survey. However, only direct management through fish removal could help to restore populations as ponds and lakes are usually permanent.

\section{Conclusions}

Land use and running waters are targeted by major legislation and funding programs (EU Water Framework Directive 2000, Young et al. 2005, Rounsevell et al. 2006). However, small lentic freshwater habitats, such as ponds and mountain lakes, are often disregarded (Nicolet et al. 2009, Oertli et al. 2010, Boix et al. 2012, Sayer 2014). As shown here, freshwater habitats can show a higher degradation than terrestrial landscapes, even within areas that are considered traditionally managed. In particular, introduced species were shown in the present case to have a stronger effect on amphibian decline and on the almost extinct emblematic paedomorphic phenotype than be those of climate change (see also Ficetola et al. 2018). Therefore, it is urgent that ponds and small lakes receive as much attention as large lakes and rivers in conservation policy (Davies et al. 2008). Such a target would need a better recognition of these habitats for preserving intra- and interspecific biodiversity value and an improvement of the ecosystemic value of freshwater habitats without alien fish introductions.

\section{ACKNOWLEDGMENTS}

We are very grateful to Ana Ivanović for sharing her observations and giving us support during this study, particularly for access to the museum collection in Belgrade. We also thank the reviewers for their constructive comments on our manuscript. The study permit of newts was issued by Agencija Zaštitu Životne Stredine of Podgorica. Thanks also to M. Breuil, R. Manenti, S. Maric, D. Mrdak, and J. Speybroek for sharing information. M. Denoël is a Research Director of the Fonds de la Recherche Scientifique-FNRS, B. Lejeune was a PhD student of the Fonds pour la Formation à la Recherche dans l'Industrie et dans l'Agriculture (FRIA), and N. Sillero is supported by an IF contract (IF/01526/2013) from Fundação para a Ciência e a Tecnologia (FCT, Portugal). This research benefited from a F.R.S.-FNRS (Fonds de la Recherche Scientifique) grant J.0112.16, a Fonds Spéciaux pour la Recherche grant C15/63 (University of Liège) and a Ministry of Education, Science and Technological Development of Republic of Serbia grant 173043.

\section{Literature Cited}

Abell, R., B. Lehner, M. Thieme, and S. Linke. 2017. Looking beyond the fenceline: assessing protection gaps for the world's rivers. Conservation Letters 10:383-393.

Arntzen, J. W., C. Abrahams, W. R. M. Meilink, R. Iosif, and A. Zuiderwijk. 2017. Amphibian decline, pond loss and 
reduced population connectivity under agricultural intensification over a 38 year period. Biodiversity and Conservation 26:1411-1430.

Bignal, E. M., and D. I. McCracken. 2000. The nature conservation value of European traditional farming systems. Environmental Reviews 8:149-171.

Bivand, R., V. Gómez-Rubio, and H. Rue. 2015. Spatial data analysis with R-INLA with some extensions. Journal of Statistical Software 63:1-31.

Bivand, R., Z. Sha, L. Osland, and I. S. Thorsen. 2017. A comparison of estimation methods for multilevel models of spatially structured data. Spatial Statistics 21:440-459.

Boix, D., J. Biggs, R. Céréghino, A. P. Hull, T. Kalettka, and B. Oertli. 2012. Pond research and management in Europe: "Small is Beautiful." Hydrobiologia 689:1-9.

Bonett, R. M., and A. L. Blair. 2017. Evidence for complex life cycle constraints on salamander body form diversification. Proceedings of the National Academy of Sciences USA 114:9936-9941.

Bonett, R. M., M. A. Steffen, S. M. Lambert, J. J. Wiens, and P. T. Chippindale. 2014. Evolution of paedomorphosis in plethodontid salamanders: Ecological correlates and re-evolution of metamorphosis. Evolution 68:466-482.

Bosch, J., S. Fernández-Beaskoetxea, T. W. J. Garner, and L. M. Carrascal. 2018. Long-term monitoring of an amphibian community after a climate change- and infectious disease-driven species extirpation. Global Change Biology 24:26222632.

Breuil, M. 1985. Etude des mesures possibles pour assurer la protection des biotopes de Tritons alpestres Triturus alpestris du Parc National des Ecrins. Rapport du Marché d'étude 69/ 84. Parc National des Ecrins, Gap, France.

Bucciarelli, G. M., A. R. Blaustein, T. S. Garcia, and L. B. Kats. 2014. Invasion complexities: The diverse impacts of nonnative species on amphibians. Copeia 2014:611-632.

Cabrera-Guzmán, E., C. Díaz-Paniagua, and I. Gomez-Mestre. 2017. Competitive and predatory interactions between invasive mosquitofish and native larval newts. Biological Invasions 19:1449-1460.

Ćirović, R. 2009. Mrmoljci (rodovi: Triturus Rafinesque, 1815 Mesotriton Bolkay, 1927, i Lissotriton Bell, 1839; Salamandridae) karsta Crne Gore-osnove zastite i ocuvanja. PhD Thesis. Univerzitet u Podgorici, Podgorica, Montenegro.

Contreras, V., E. Martinez-Meyer, E. Valiente, and L. Zambrano. 2009. Recent decline and potential distribution in the last remnant area of the microendemic Mexican axolotl (Ambystoma mexicanum). Biological Conservation 142:2881-2885.

Crochet, P. A., O. Chaline, M. Cheylan, and C. P. Guillaume. 2004. No evidence of general decline in an amphibian community of southern France. Biological Conservation 119:297304.

Cruickshank, S. S., A. Ozgul, S. Zumbach, and B. R. Schmidt. 2016. Quantifying population declines based on presenceonly records for red-list assessments. Conservation Biology 30:1112-1121.

Cruz, M. J., R. Rebelo, and E. G. Crespo. 2006. Effects of an introduced crayfish, Procambarus clarkii, on the distribution of south-western Iberian amphibians in their breeding habitats. Ecography 29:329-338.

Davies, B., J. Biggs, P. Williams, M. Whitfield, P. Nicolet, D. Sear, S. Bray, and S. Maund. 2008. Comparative biodiversity of aquatic habitats in the European agricultural landscape. Agriculture, Ecosystems \& Environment 125:1-8.

Denoël, M. 2012. Newt decline in Western Europe: highlights from relative distribution changes within guilds. Biodiversity and Conservation 21:2887-2898.
Denoël, M. 2017. On the identification of paedomorphic and overwintering larval newts based on cloacal shape: review and guidelines. Current Zoology 63:165-173.

Denoël, M., and G. F. Ficetola. 2007. Landscape level thresholds and newt conservation. Ecological Applications 17:302309

Denoël, M., and L. Winandy. 2015. The importance of phenotype diversity in conservation: Resilience of palmate newt morphotypes after fish removal in Larzac ponds (France). Biological Conservation 192:402-408.

Denoël, M., R. Duguet, G. Džukić, M. L. Kalezić, and S. Mazzotti. 2001. Biogeography and ecology of paedomorphosis in Triturus alpestris (Amphibia, Caudata). Journal of Biogeography 28:1271-1280.

Denoël, M., G. Džukić, and M. L. Kalezić. 2005a. Effect of widespread fish introductions on paedomorphic newts in Europe. Conservation Biology 19:162-170.

Denoël, M., H. H. Whiteman, and P. Joly. 2005b. Evolutionary ecology of facultative paedomorphosis in newts and salamanders. Biological Reviews 80:663-671.

Denoël, M., G. F. Ficetola, R. Ćirović, D. Radović, G. Džukić, M. L. Kalezić, and T. D. Vukov. 2009. A multi-scale approach to facultative padomorphosis of European newts in the Montenegrin karst: distribution pattern, environmental variables and conservation. Biological Conservation 142:509-517.

Denoël, M., A. Perez, Y. Cornet, and G. F. Ficetola. 2013. Similar local and landscape processes affect both a common and a rare newt species. PLoS ONE 8:e62727.

Diaz-Nieto, J., and R. L. Wilby. 2005. A comparison of statistical downscaling and climate change factor methods: impacts on low flows in the River Thames, United Kingdom. Climatic Change 69:245-268.

Drechsler, A., D. Ortmann, and S. Steinfartz. 2016. How do we deal with species of the habitats Directive - The crash of one of the largest great crested newt populations (Triturus cristatus) on record to the edge of extinction. Zeitschrift fur Feldherpetologie 23:181-202.

Dudgeon, D., et al. 2006. Freshwater biodiversity: importance, threats, status and conservation challenges. Biological Reviews 81:163-182.

Dufresnes, C., and N. Perrin. 2015. Effect of biogeographic history on population vulnerability in European amphibians. Conservation Biology 29:1235-1241.

Džukić, G. 1981. Prvi nalaz neotenicne populacije malog mrmoljka Triturus vulgaris (Linnaeus), 1758 in Yugoslavia. Glasnik Republicki Zavod za Zdravstvenu Zastitu PrirodePrirodnjackog Muzeja Titograd 14:71-77.

Džukić, G. 1995. Diversitet vodozemaca (Amphibia) i gmizavaca (Reptilia) Jugoslavije sa pregledom vrsta od medjunarodnog znacaja. Pages 447-469 in V. Stevanović and V. Vasić, editors. Biodiverzitet Jugoslavije sa pregledom vrsta of medjunarodnog znacaja. Bioloski Fakultet i Ecolibri, Belgrade, Serbia.

Džukić, G., M. L. Kalezić, M. Tvrtković, and A. Djorović. 1990. An overview of the occurrence of paedomorphosis in Yugoslav newt (Triturus, Salamandridae) populations. British Herpetological Society Bulletin 34:16-22.

Džukić, G., M. Cvijanović, A. Urošević, T. D. Vukov, N. Tomasevic Kolarov, M. Slipjepcević, A. Ivanović, and M. L. Kalezić. 2015. The batrachological collections of the Institute for Biological Research "Siniša Stanković." Bulletin of the Natural History Museum 8:118-167.

EU Water Framework Directive. 2000. Directive 2000/60/EC of the European Parliament and of the council of 23 October 2000 establishing a framework for community action in the field of water policy. Official Journal of the European Communities 327:1-72. 
Ferreira, M., and P. Beja. 2013. Mediterranean amphibians and the loss of temporary ponds: Are there alternative breeding habitats? Biological Conservation 165:179-186.

Ficetola, G. F., and L. Maiorano. 2016. Contrasting effects of temperature and precipitation change on amphibian phenology, abundance and performance. Oecologia 181: 683-693.

Ficetola, G. F., L. Maiorano, A. Falcucci, N. Dendoncker, L. Boitani, E. Padoa-Schioppa, C. Miaud, and W. Thuiller. 2010. Knowing the past to predict the future: Land-use change and the distribution of invasive bullfrogs. Global Change Biology 16:528-537.

Ficetola, G. F., M. E. Siesa, R. Manenti, L. Bottoni, F. De Bernardi, and E. Padoa-Schioppa. 2011. Early assessment of the impact of alien species: Differential consequences of an invasive crayfish on adult and larval amphibians. Diversity and Distributions 17:1141-1151.

Ficetola, G. F., M. E. Siesa, F. De Bernardi, and E. PadoaSchioppa. 2012. Complex impact of an invasive crayfish on freshwater food webs. Biodiversity and Conservation 21:2641-2651.

Ficetola, G. F., et al. 2018. DNA from lake sediments reveals long-term ecosystem changes after a biological invasion. Science Advances 4:eaar4292.

Fischer, J., T. Hartel, and T. Kuemmerle. 2012. Conservation policy in traditional farming landscapes. Conservation Letters 5:167-175.

Fiske, I., and R. Chandler. 2011. Unmarked: an R package for fitting hierarchical models of wildlife occurrence and abundance. Journal of Statistical Software 43:1-23.

Gallardo, B., M. Clavero, M. I. Sánchez, and M. Vilà. 2016. Global ecological impacts of invasive species in aquatic ecosystems. Global Change Biology 22:151-163.

Gamradt, S. C., and L. B. Kats. 1996. Effect of introduced crayfish and mosquitofish on California newts. Conservation Biology 10:1155-1162.

Gherardi, F. 2010. Invasive crayfish and freshwater fishes of the world. Revue Scientifique et Technique 29:241-254.

Gordon, L. J., C. M. Finlayson, and M. Falkenmark. 2010. Managing water in agriculture for food production and other ecosystem services. Agricultural Water Management 97:512519.

Gould, S. J. 1977. Ontogeny and phylogeny. Harvard University Press, Cambridge, Massachusetts, USA.

Griffiths, H. I., B. Kryštufek, and J. M. Reed, editors. 2004. Balkan biodiversity. Pattern and process in the European hotspot. Springer, Dordrecht, The Netherlands.

Hammitt, W. E., M. E. Patterson, and F. P. Noe. 1994. Identifying and predicting visual preference of southern Appalachian forest recreation vistas. Landscape and Urban Planning 29:171-183.

Harris, I., P. Jones, T. Osborn, and D. Lister. 2014. Updated high-resolution grids of monthly climatic observations-the CRU TS3. 10 Dataset. International Journal of Climatology 34:623-642.

Hartel, T., and H. von Wehrden. 2013. Farmed areas predict the distribution of amphibian ponds in a traditional rural landscape. PLoS ONE 8:e63649.

Hartel, T., O. Schweiger, K. Öllerer, D. Cogalniceanu, and J. W. Arntzen. 2010. Amphibian distribution in a traditionally managed rural landscape of Eastern Europe: Probing the effect of landscape composition. Biological Conservation 143:1118-1124

Hartel, T., T. Sos, V. D. Popescu, R. I. Băncilă, D. Cogălniceanu, and L. Rozylowicz. 2014. Amphibian conservation in traditional cultural landscapes: The case of Central Romania. North-Western Journal of Zoology 10:S51-S61.
Havel, J. E., K. E. Kovalenko, S. M. Thomaz, S. Amalfitano, and L. B. Kats. 2015. Aquatic invasive species: challenges for the future. Hydrobiologia 750:147-170.

IUCN. 2017. Guidelines for Using the IUCN Red List Categories and Criteria. Version 13. http://www.iucnredlist.org/ documents/RedListGuidelines.pdf:IUCN

Jehle, R., and J. W. Arntzen. 2000. Post-breeding migrations of newts (Triturus cristatus and T. marmoratus) with contrasting ecological requirements. Journal of Zoology, London 251:297-306.

Kalezić, M. L., and G. Džukić. 1985. Ecological aspects of the smooth newt (Triturus vulgaris) paedomorphosis from Montenegro. Arhiv Bioloskih Nauka 37:43-50.

Kalezić, M. L., and G. Dzukiž. 1986. The frequent occurrence of paedomorphosis in the smooth newt (Triturus vulgaris) population from the submediterranean area of Yugoslavia. Amphibia-Reptilia 7:86-89.

Kalezić, M. L., G. Džukić, and A. Popadić. 1989. Paedomorphosis in Yugoslav Alpine newt (Triturus alpestris) populations: morphometric variability and sex ratio. Arhiv Bioloskih Nauka, Beograd 41:67-79.

Kalezić, M. L., D. Cvetković, A. Djorović, and G. Džukić. 1996. Alternative life-history pathways: paedomorphosis and adult fitness in European newts (Triturus vulgaris and $T$. alpestris). Journal of Zoological Systematics and Evolutionary Research 34:1-7.

Karger, D. N., O. Conrad, J. Böhner, T. Kawohl, H. Kreft, R. W. Soria-Auza, N. E. Zimmermann, H. P. Linder, and M. Kessler. 2017. Climatologies at high resolution for the earth's land surface areas. Scientific Data 4:170122.

Knapp, R. A., and K. R. Matthews. 1998. Eradication of nonnative fish by gill netting from a small mountain lake in California. Restoration Ecology 6:207-213.

Knapp, R. A., and K. R. Matthews. 2000. Non-native fish introductions and the decline of the mountain yellow-legged frog from within protected areas. Conservation Biology $14: 428-438$.

Knapp, R. A., K. R. Matthews, and O. Sarnelle. 2001. Resistance and resilience of alpine lake fauna to fish introductions. Ecological Monographs 71:401-421.

Knapp, R. A., D. M. Boiano, and V. T. Vredenburg. 2007. Removal of nonnative fish results in population expansion of a declining amphibian (mountain yellow-legged frog, Rana muscosa). Biological Conservation 135:11-20.

Knapp, R. A., G. M. Fellers, P. M. Kleeman, D. A. W. Miller, V. T. Vredenburg, E. B. Rosenblum, and C. J. Briggs. 2016. Large-scale recovery of an endangered amphibian despite ongoing exposure to multiple stressors. Proceedings of the National Academy of Sciences USA 113:11889-11894.

Lakovic, I., S. Pekovic, D. Statuto, and P. Picuno. 2016. The katuns-rural buildings as a perspective of seasonal mountain settlements in Montenegro. Pages 557-566 in Proceedings of the 44th International Symposium on Agricultural Engineering: Actual Tasks on Agricultural Engineering, Opatija, Croatia, 23-26 February 2016. University of Zagreb, Faculty of Agriculture, Zagreb, Croatia.

Lejeune, B., N. Sturaro, G. Lepoint, and M. Denoël. 2018. Facultative paedomorphosis as a mechanism promoting intraspecific niche differentiation. Oikos 127:427-439.

MacKenzie, D. I., J. D. Nichols, J. A. Royle, K. H. Pollock, L. Bailey, and J. E. Hines. 2017. Occupancy estimation and modeling: inferring patterns and dynamics of species occurrence. Academic Press, Burlington, Massachusetts, USA.

Mathiron, A. G. E., J.-P. Lena, S. Baouch, and M. Denoël. 2017. The 'male escape hypothesis': sex-biased metamorphosis in response to climatic drivers in a facultatively 
paedomorphic amphibian. Proceedings of the Royal Society B 284:20170176.

Milligan, W. R., M. T. Jones, L. B. Kats, T. A. Lucas, and C. L. Davis. 2017. Predicting the effects of manual crayfish removal on California newt persistence in Santa Monica Mountain streams. Ecological Modelling 352:139-151.

Miró, A., and M. Ventura. 2013. Historical use, fishing management and lake characteristics explain the presence of nonnative trout in Pyrenean lakes: Implications for conservation. Biological Conservation 167:17-24.

Miró, A., I. Sabás, and M. Ventura. 2018. Large negative effect of non-native trout and minnows on Pyrenean lake amphibians. Biological Conservation 218:144-153.

Mittermeier, R. A., P. R. Gil, M. Hoffmann, J. Pilgrim, T. Brooks, C. G. Mittermeier, J. Lamoreux, and G. A. B. Da Fonseca, editors. 2004. Hotspots revisited. CEMEX, Mexico City, Mexico.

Nicolet, P., A. Ruggiero, and J. Biggs. 2009. Second European pond workshop: Conservation of pond biodiversity in a changing European landscape. International Journal of Limnology 43:77-80.

Nyssen, J., J. V. Branden, V. Spalević, A. Frankl, L. Van de velde, M. Čurović, and P. Billi. 2014. Twentieth century land resilience in Montenegro and consequent hydrological response. Land Degradation and Development 25:336-349.

Oertli, B., J. Biggs, R. Céréghino, S. Declerck, A. Hull, and M. R. Miracle. 2010. Pond conservation in Europe. Springer, Dordrecht, The Netherlands.

Orizaola, G., and F. Braña. 2006. Effect of salmonid introduction and other environmental characteristics on amphibian distribution and abundance in mountain lakes of northern Spain. Animal Conservation 9:171-178.

Oromi, N., J. Michaux, and M. Denoël. 2016. High gene flow between alternative morphs and the evolutionary persistence of facultative paedomorphosis. Scientific Reports 6:32046.

Oromi, N., E. Valbuena-Ureña, A. Soler-Membrives, F. Amat, S. Camarasa, S. Carranza, D. Sanuy, and M. Denoël. 2019. Genetic structure of lake and stream populations in a Pyrenean amphibian (Calotriton asper) reveals evolutionary significant units associated with paedomorphosis. Journal of Zoological Systematics and Evolutionary Research. In press. https://doi.org/10.1111/jzs. 12250

Papaioannou, H., A. Batistatou, M. C. Mavrogiorgou, C. Konidaris, S. Frillingos, E. Briasoulis, K. Vareli, and I. Sainis. 2015. High incidence of dorsal dark spots in north-western Greek populations of alpine newts Ichthyosaura alpestris (Salamandridae, Caudata). Herpetology Notes 8:589-598.

Pătru-Stupariu, I., C. A. Tudor, M. S. Stupariu, A. Buttler, and A. Peringer. 2016. Landscape persistence and stakeholder perspectives: The case of Romania's Carpathians. Applied Geography 69:87-98.

Pilliod, D. S., B. R. Hossack, P. F. Bahls, E. L. Bull, P. S. Corn, G. Hokit, B. A. Maxell, J. C. Munger, and A. Wyrick. 2010. Non-native salmonids affect amphibian occupancy at multiple spatial scales. Diversity and Distributions 16:959-974.

Plăiaşu, R., R. Băncilă, C. Samoilă, T. Hartel, and D. Cogălniceanu. 2012. Waterbody availability and use by amphibian communities in a rural landscape. Herpetological Journal 22:13-21.

Radovanović, M. 1951. A new race of the Alpine newt from Yugoslavia. British Journal of Herpetology 1:93-97.

Radovanović, M. 1961. Neue Fundorte neotenischer Bergmolche in Jugoslawien. Zoologischer Anzeiger 166:206-218.

Ricciardi, A., and J. B. Rasmussen. 1999. Extinction rates of North American freshwater fauna. Conservation Biology 13:1220-1222.
Rodríguez, C. F., E. Bécares, M. Fernández-Aláez, and C. Fernández-Aláez. 2005. Loss of diversity and degradation of wetlands as a result of introducing exotic crayfish. Biological Invasions 7:75-85.

Rotherham, I. D. 2015. Bio-cultural heritage and biodiversity: emerging paradigms in conservation and planning. Biodiversity and Conservation 24:3405-3429.

Rounsevell, M. D. A., et al. 2006. A coherent set of future land use change scenarios for Europe. Agriculture, Ecosystems \& Environment 114:57-68.

Rue, H., A. Riebler, S. H. Sørbye, J. B. Illian, D. P. Simpson, and F. K. Lindgren. 2017. Bayesian computing with INLA: a review. Annual Review of Statistics and Its Application 4:395-421.

Sala, O. E., et al. 2000. Global biodiversity scenarios for the year 2100. Science 287:1770-1774.

Sayer, C. D. 2014. Conservation of aquatic landscapes: ponds, lakes, and rivers as integrated systems. Wiley Interdisciplinary Reviews: Water 1:573-585.

Schabetsberger, R., and C. D. Jersabek. 1995. Alpine newts (Triturus alpestris) as top predators in a high-altitude karst lake: daily food-consumption and impact on the copepod Arctodiaptomus alpinus. Freshwater Biology 33:47-61.

Scheffers, B. R., D. P. Edwards, A. Diesmos, S. E. Williams, and T. A. Evans. 2014. Microhabitats reduce animal's exposure to climate extremes. Global Change Biology 20:495-503.

Semlitsch, R. D. 1998. Biological delineation of terrestrial buffer zones for pond-breeding salamanders. Conservation Biology $12: 1113-1119$.

Semlitsch, R. D. 2003. Conservation of pond-breeding amphibians. Pages 8-23 in R. D. Semlitsch, editor. Amphibian conservation. Smithsonian, Washington, D.C., USA.

Semlitsch, R. D., and J. W. Gibbons. 1985. Phenotypic variation in metamorphosis and paedomorphosis in the salamander Ambystoma talpoideum. Ecology 66:1123-1130.

Semlitsch, R. D., and H. M. Wilbur. 1989. Artificial selection for paedomorphosis in the salamander Ambystoma talpoideum. Evolution 43:105-112.

Sotiropoulos, K., K. Moustakas, K. Konstantinidis, V. Mantzana-Oikonomaki, S. Siarabi, and A. Bounas. 2017. First record of facultative paedomorphosis in the Macedonian crested newt (Triturus macedonicus) and an additional record for the Greek smooth newt (Lissotriton vulgaris) from Greece: implications on species conservation and preservation of alternative ontogenetic trajectories. Herpetology Notes 10:255-260.

Stoate, C., A. Báldi, P. Beja, N. D. Boatman, I. Herzon, A. van Doorn, G. R. de Snoo, L. Rakosy, and C. Ramwell. 2009. Ecological impacts of early 21 st century agricultural change in Europe-A review. Journal of Environmental Management 91:22-46.

Tiberti, R. 2018. Can satellite ponds buffer the impact of introduced fish on newts in a mountain pond network? Aquatic Conservation: Marine and Freshwater Ecosystems 28:457465.

Tiberti, R., L. Nelli, S. Brighenti, R. Iacobuzio, and M. Rolla. 2017. Spatial distribution of introduced brook trout Salvelinus fontinalis (Salmonidae) within alpine lakes: evidences from a fish eradication campaign. European Zoological Journal 84:73-88.

Vorosmarty, C. J., et al. 2010. Global threats to human water security and river biodiversity. Nature 467:555-561.

Voss, S. R., and H. B. Shaffer. 1997. Adaptive evolution via a major gene effect: Paedomorphosis in the Mexican axolotl. Proceedings of the National Academy of Sciences USA 94:14185-14189. 
Vredenburg, V. T. 2004. Reversing introduced species effects: Experimental removal of introduced fish leads to rapid recovery of a declining frog. Proceedings of the National Academy of Sciences USA 101:7646-7650.

Walls, S. C. 2009. The role of climate in the dynamics of a hybrid zone in Appalachian salamanders. Global Change Biology 15:1903-1910.

Whiteman, H. H., and R. D. Howard. 1998. Conserving alternative amphibian phenotypes: Is there anybody out there? Pages 317-324 in M. J. Lannoo, editor. The status and conservation of Midwestern amphibians. Iowa University Press, Iowa City, Iowa, USA.

Wielstra, B., et al. 2018. The distributions of the six species constituting the smooth newt species complex (Lissotriton vulgaris sensu lato and L. montandoni) - an addition to the New Atlas of amphibians and reptiles of Europe. Amphibia-Reptilia 39:252-259.

Williams, P., M. Whitfield, J. Biggs, S. Bray, G. Fox, P. Nicolet, and D. Sear. 2004. Comparative biodiversity of rivers, streams, ditches and ponds in an agricultural landscape in Southern England. Biological Conservation 115:329-341.
Winandy, L., and M. Denoël. 2015. The aggressive personality of an introduced fish affects foraging behavior in a polymorphic newt. Behavioral Ecology 26:1528-1536.

Winandy, L., E. Darnet, and M. Denoël. 2015. Amphibians forgo aquatic life in response to alien fish introduction. Animal Behaviour 109:209-216.

Winandy, L., P. Legrand, and M. Denoël. 2017. Habitat selection and reproduction of newts in networks of fish and fishless aquatic patches. Animal Behaviour 123:107115.

Wood, P. J., M. T. Greenwood, and M. D. Agnew. 2003. Pond diversity and habitat loss in the UK. Area 35:206-216.

Young, J., et al. 2005. Towards sustainable land use: identifying and managing the conflicts between human activities and biodiversity conservation in Europe. Biodiversity \& Conservation 14:1641-1661.

Zambrano, L., E. Valiente, and M. J. Vander Zanden. 2010. Food web overlap among native axolotl (Ambystoma mexicanum) and two exotic fishes: carp (Cyprinus carpio) and tilapia (Oreochromis niloticus) in Xochimilco, Mexico City. Biological Invasions 12:3061-3069.

\section{SUPPORTING INFORMATION}

Additional supporting information may be found online at: http://onlinelibrary.wiley.com/doi/10.1002/ecm.1347/full

\section{Data Availability}

Additional data are available from ORBi (Open Repository and Bibliography): http://hdl.handle.net/2268/229377. 